\title{
Nominee to lead US health care accused of insider trading
}

Cite as: CMAJ 2017 February 6;189:E221. doi: 10.1503/cmaj.1095382

$\mathrm{T}$ he nominee for the top government health care job in the United States is facing accusations of insider trading. Dr. Tom Price, an orthopedic surgeon and Georgia congressman, has been tapped by PresidentElect Donald Trump to run the Health and Human Services Department (HHS). But several Democrats have called for the Office of Congressional Ethics to investigate claims that Price used his influence as a congressman to forward the interests of companies in which he had investments.

According to the Wall Street Journal, Price has invested in about 40 companies in the pharmaceutical, biomedical and other health care sectors, and "traded more than $\$ 300000$ in shares of healthrelated companies over the past four years while sponsoring and advocating legislation that potentially could affect those companies' stocks."

Senator Minority Leader Chuck Schumer has referred to these allegations as shocking and said there is enough evidence to warrant an investigation. He even tweeted that "Tom Price puts profit over people."

Price does, however, have the support of several influential medical orga- nizations. The American Medical Association (AMA) released a statement indicating it "strongly supports" the nomination of Price to become the next health secretary. The association praised Price for developing health policies to advance patient choice and reducing "excessive regulatory burdens that diminish time devoted to patient care and increase costs."

When contacted for comment on its support for Price, the AMA directed CMAJ to a statement from its board chair, Dr. Patrice Harris. According to Harris, the AMA's endorsement is based on decades of interaction with Price. And though Harris acknowledged she doesn't always agree with Price on policy issues, she praised him for his consistency in two areas: "his understanding of the many challenges facing patients and physicians today, and his willingness to listen directly to concerns expressed by the AMA and other physician organizations."

The American Hospital Association (AHA) also endorsed Price's nomination, stating that his clinical knowledge as an orthopedic surgeon combined with his congressional experience makes him "an impressively qualified" candidate to lead the HHS. CMAJ has not yet received a response from an inquiry to the AHA regarding its support for Price.

Another controversy surrounding Price, according to Kaiser Health News, is his history of petitioning the US Food and Drug Administration (FDA) on behalf of pharmaceutical companies and medicaldevice makers that contributed money to his political campaigns. In a letter to the FDA, for example, he referred to one these companies as a "pillar of the community" and requested that it be exempted from having to perform a clinical trial that would be "impossible to pass."

In its extensive investigation into Price, Kaiser Health News also noted that the congressman opposes the Affordable Care Act and wants it repealed. He also introduced a bill to delay cuts to Medicare spending on medical equipment (medical-equipment companies are among his most generous political donors), helped protect the interests of home care companies (which have given him more than US\$24000 since 2013) and supported legislation to protect the tax status of "travelling doctor" companies that find short-term contracts for physicians.

Roger Collier, CMAJ 